\title{
The Cyclical Behaviour of Fiscal Policy: Evidence from the OECD
}

\author{
Philip R. Lane* \\ Institute for International Integration Studies, Trinity College Dublin \\ and CEPR
}

February 2002

\begin{abstract}
This paper addresses the topic of cyclicality in fiscal policy. In particular, we show that the level of cyclicality varies across spending categories and across OECD countries. In line with leading theories of fiscal cyclicality, we show that countries with volatile output and dispersed political power are the most likely to run procyclical fiscal policies. Wage government consumption is highlighted as the most important channel by which these variables affect fiscal cyclicality.
\end{abstract}

Keywords: fiscal policy, volatility, voracity.

JEL Codes: E62, H50, H60.

*Economics Department, Trinity College Dublin, Dublin 2, Ireland. Email: plane@tcd.ie. Tel.:353-1-608 2259. Fax: 3531-6772503. I thank the three anonymous referees and participants in the LACEA 1999 (Santiago) conference for comments. Anke Heydenreich provided excellent research assistance. Financial support was provided by the Social Science Research Council of the Royal Irish Academy, the TCD Provost's Academic Development Fund and the TCD BESS Benefactions Fund for financial support. 


\section{Introduction}

The behavior of fiscal policy over the business cycle has received increasing attention from researchers in recent years. Although, in broad terms, the conventional wisdom is that fiscal policy should be countercyclical, evidence of procyclicality in fiscal policy has been uncovered in a number of studies. Much of this work has focused on Latin America (Gavin et al. 1996, Gavin and Perotti 1997, Stein et al 1999). However, Talvi and Vegh (1999) show that fiscal procyclicality is evident in a much wider sample of countries and Lane (1998) also finds procyclicality in a single-country time series study of Irish fiscal policy. ${ }^{1}$

In this paper, we study the cyclicality of fiscal policy in a sample of OECD countries. An OECD study offers several advantages. First, a longer span of data is available for the OECD than for developing countries. Second, data quality and cross-country comparability are also likely to be of a higher standard for the OECD. Third, in contrast to a Latin American sample, it is unlikely that government debt constraints have seriously restricted fiscal policy among the rich OECD countries such that any evidence of procyclicality cannot be rationalized by externally-imposed fiscal corrections during downturns.

This paper makes two main contributions. First, we calculate regression-based cyclicality indicators for disaggregated components of fiscal policy on a country-by-country basis for a set of OECD countries. A disaggregated approach is potentially useful in highlighting the components of government spending that are most prone to procyclicality. Furthermore, only examining broad aggregates can be misleading if subcomponents move in offsetting ways. Identifying differences in cyclical behavior across spending categories may stimulate further theoretical research and may also be useful in making projections about future fiscal trends. Moreover, the work of Alesina and Perotti (1995) establishes that the composition of government spending is critical in determining the success of attempts at fiscal adjustment.

Second, as we will show in section 3, countries vary greatly in the degree of cyclicality exhibited in fiscal policy. We seek to explain the cross-country variation in the degree of fiscal cyclicality by a set of country characteristics. A recent political economy literature

\footnotetext{
${ }^{1}$ Agenor et al (1999) study fiscal cyclicality for a small number of developing countries.
} 
(discussed in section 2 below) has identified some features that may help to explain this cross-country variation. We consider two variables that are inspired by this theoretical literature: the level of output volatility and an index of "power dispersion". We also include output per capita, trade openness and the size of the public sector as general control variables. In a European context, the analysis of differences in fiscal procyclicality across countries is also relevant in understanding the potentially country-varying political pressures generated by the fiscal restrictions that are built into the Growth and Stability Pact.

This work is related to a number of other recent papers. For a sample of Latin American countries, Stein et al (1999) show that output volatility and a measure of political competition (the average number of representatives elected per district) are helpful in explaining the cross-section variation in the cyclicality of government consumption. In contrast, we adopt a new measure of power dispersion, examine a wider range of government spending measures and focus on an OECD sample. Sorensen et al (2001) seek to explain the variation in fiscal cyclicality across US states by characteristics such as average output levels, the stock of long-term debt and a balanced-budget stringency index. ${ }^{2}$ These authors focus on the primary surplus rather than on public spending. Restrictions on the scope of public spending and the size of budget deficits also mean that evidence about statelevel governments in a federal system do not necessarily generalize to the case of sovereign governments.

A number of authors have previously studied fiscal cyclicality in OECD data. In particular, Arreaza et al (1999) generate panel-based estimates of the degree of cyclicality in government consumption, transfers, subsidies and (indirect and direct) tax revenues and find that fiscal surpluses are on average procyclical and government consumption is also weakly procyclical. ${ }^{3}$ They do permit some cross-country heterogeneity by exploring sample splits in which countries are split according to differences in the average level of the budget deficit and in the design of fiscal institutions. However, we allow a greater role for

\footnotetext{
${ }^{2}$ An early study of fiscal cyclicality across US states is Bayoumi and Eichengreen (1995).

${ }^{3}$ Government consumption varies positively but less than proportionately with output fluctuations. Hercowitz and Strawczynski (1999) also study OECD data. Their focus is on tracking the growth in the overall size of government via asymmetric fiscal responses to booms and recessions.
} 
heterogeneity by performing country-by-country regressions and perform a more detailed decomposition of government spending. Moreover, as is indicated above, we seek to exploit a set of theory-inspired country characteristics in order to explain the determinants of cyclical heterogeneity across the OECD.

The structure of the rest of the paper is as follows. Section 2 briefly outlines the theoretical issues in thinking about fiscal cyclicality. Section 3 discusses the data and regression specifications. Section 4 presents and interprets the empirical results. Finally, conclusions are offered in section 5.

\section{Fiscal Cyclicality: Theoretical Issues}

In this section, we review the economic arguments regarding optimal cyclicality in fiscal policy. As indicated in the introduction, our primary interest is in the political determinants that lead to variation in fiscal cyclicality across countries but it is still useful to discuss the choices that would be made by a 'benevolent dictator' fiscal administration as a theoretical reference point.

\subsection{Fiscal Cyclicality: A Benchmark}

The most well-known theoretical statement regarding fiscal cyclicality is the 'tax-smoothing' hypothesis that, for a given path of government spending, tax rates should be held constant over the business cycle and the budget surplus should move in a procyclical fashion (Barro 1979). Our focus is on the cyclicality of government spending rather than on its financing. ${ }^{4}$ At a cyclical frequency, there is a large autonomous component to fluctuations in tax revenues: it is more interesting to examine the spending dimension since the scope for discretionary policy is much broader. Here, the theoretical literature is relatively silent: the typical assumption in neoclassical analysis of fiscal policy is that government spending is exogenously determined, if possibly stochastic (Stokey and Lucas 1983, Blanchard and Fischer 1989, Taylor and Woodford 1999).

\footnotetext{
${ }^{4}$ That said, we do also study the primary surplus to see if cyclicality in spending translates into cyclicality in the budget deficit or tax revenues.
} 
However, from a Keynesian perspective, there is a clear view that public expenditure should act as a stabilizing force and move in a countercyclical direction. For stabilization purposes, the different items of government spending should be ranked according to their multiplier values.

As noted, however, the theoretical conjectures are weaker in a neoclassical framework. If government spending is endogenized, the optimal comovement between government consumption and private consumption depends on the degree of substitutability in utility between these two items. If public and private components are substitutes, we should expect to see government consumption move countercyclically; if complements, alternatively, the pattern would be procyclical. If public and private consumption are separable in utility, finally, the government should seek to perfectly smooth government consumption over the business cycle. ${ }^{5}$

Regarding optimal public investment, its cyclical behavior similarly depends on whether public capital is a complement or substitute for that factor or factors whose current productivity is affected by current disturbances (Blanchard and Fischer 1989, p591). Another consideration is that the multi-year nature of large-scale government capital projects means that public investment is most appropriately analyzed in a long-run growth framework (eg Barro and Sala-i-Martin 1995). However, even if public investment plans are formulated with a long-run focus, their execution may optimally display a countercyclical pattern if the relative price of public investment declines during downturns. Public investment should also move countercyclically according to Keynesian demand management principles.

With respect to government transfers - an major component of government current spending - in-built automatic stabilizers should generate a countercyclical pattern as the number of claimants falls during expansions and rises during recessions. However, this could be to some extent offset if benefit rates move in the opposite direction, which depends on the nature of the political equilibrium in a country.

\footnotetext{
${ }^{5}$ Arreaza et al (1999) also investigate the role of smoothing of government consumption in stabilizing total consumption but restrict behavior to be the same across the OECD countries, whereas we focus on the differences across countries. Moreover, the relation between government and total consumption is not strongly determined, since it depends on the substitutability/complementarity between government and private consumption in the utility function. It would be an interesting study to relate private consumption behavior to cyclicality in government consumption but that is beyond the scope of this paper.
} 
Finally, the cyclical behavior of debt interest payments depends both on the cyclical behavior of interest rates and the design of the public debt. Regarding the latter, strategic debt managers may attempt to induce a procyclical pattern in debt payments, since the government can better afford high debt payments during boom periods (Missale 1999).

\subsection{Political Economy of Fiscal Cyclicality}

The discussion in the previous subsection highlighted that neoclassical analysis makes weak predictions concerning the cyclical behavior of government expenditures and that a Keynesian framework suggests a countercyclical pattern. In recent work, some authors have appealed to political economy factors to generate a procyclical bias in public spending.

Lane and Tornell $(1996,1998)$ and Tornell and Lane $(1996,1999)$ develop a framework in which multiple power blocs compete for a share in fiscal revenues. The notion of multiple powerful fiscal groups is open to a number of interpretations. It can refer to different branches of government (i.e. the executive versus congress); individual parties within a coalition; or even individual ministries within the government. More broadly, it may also encompass other political claimants such as state or provincial governments within a federal system or labour unions and employer confederations in corporatist systems. An important result in this modelling approach is that the intensity of fiscal competition increases during upturns: the impact of this "voracity effect" is that spending can even grow more than proportionally relative to the increase in income. The intuition is that the incentive to act prudently is low: each group knows that if it refrains from increasing its appropriation rate during expansions, the result is not that the government runs a budget surplus but that the other groups can increase their appropriate rate by an even greater amount. ${ }^{6}$ Symmetrically, recessions have a chilling effect on fiscal competition.

Accordingly, a basic prediction of this approach is that political systems in which power is diffused among a number of agents will witness a higher degree of fiscal procyclicality relative to a unitary system. The generality of the voracity hypothesis does not lend itself to strong predictions regarding the composition of government spending. However, it is

\footnotetext{
${ }^{6}$ This class of models studies a non-cooperative equilibrium. Svensson (1996) explores a collusive equilibrium in a parallel setup and obtains similar procyclical behavior, since the sustainability of collusion declines during booms.
} 
plausible that variation in procyclicality across different expenditure items will be influence by the specific distribution of fiscal power. For instance, powerful public sector unions may generate procyclicality especially in the level of government wages.

Talvi and Vegh (2000) similarly write a model in which political economy factors generate a procyclical bias in fiscal policy: the emergence of an incipient fiscal surplus unleashes intense lobbying for higher public spending during a boom. An important feature of the Talvi-Vegh model is that in general these spending pressures are an increasing, convex function of the incipient primary surplus - the larger the boom, the more severe is the political distortion. Accordingly, high output volatility (and the associated high tax base volatility) is the environment most conducive to generating procyclical fiscal behavior. Empirically, they show that a positive correlation exists between output volatility and the degree of procyclicality in government consumption in a large cross-section of countries.

The one-good nature of the Talvi-Vegh model means that these authors do not look directly at the composition of government spending. However, the logic of their argument is that spending pressures will vary according to the political sensitivity of the particular category: individual voters may care most about public consumption goods or transfers; business interests about infrastructure; and government employees about public sector wages. In this way, there may be differences in sectoral cyclicality depending on precise nature of the prevailing political equilibrium in terms of the distribution of political influence across such groups.

\section{Empirical Strategy}

\subsection{Data}

GDP and fiscal data are obtained from the OECD Economic Outlook database. ${ }^{7}$ All fiscal variables are converted into constant prices using the GDP deflator, since we do not want to eliminate any growth in government spending that takes the form of an increase in the relative price of public sector outputs.

\footnotetext{
${ }^{7}$ See the OECD Economic Outlook: Sources and Methods, available on the OECD website, for details on the definition and construction of these variables.
} 
We examine the following public expenditure variables: current government spending (GICURR); government consumption (GC) and its breakdown between wage and non-wage components (WGC, NWGC); government investment (GI); total government spending $($ GTOT $=$ GCURR $+\mathrm{GI})$; non-interest current and non-interest total government spending (NIGCURR; NIGTOT). We further decompose wage government consumption into public sector employment and public sector real wages (EG, PUBWAGE). We also measure these variables in relative terms: the ratio of government to total employment $(\mathrm{PUBSIZE}=\mathrm{EG} / \mathrm{ET})$ and the ratio of public- to private-sector wages (RELW). Finally, we examine the primary surplus (ie the fiscal surplus before debt interest payments) as a ratio to GDP (PSY).

Regarding the key explanatory variables, we follow the Talvi-Vegh model by including output volatility (VOL), which is measured as the standard deviation of the GDP growth rate. The measure of power dispersion is taken from Henisz $(2000)$. This $(0,1)$ index counts the number of veto points in the political system and the distribution of preferences across and within the different branches of the government. ${ }^{8}$ Power is more dispersed, the greater the number of veto points and the greater the division of control across different political parties. Henisz calculates this index for a large number of countries on an annual basis over 1960-98 and we employ the average value of the index over this interval (POLCON) in the cross-sectional analysis. Henisz shows that this index is positively associated with growth performance, with the interpretation that power dispersion enhances the security of property rights by reducing the ability of the executive branch to easily introduce legal or constitutional changes. However, according to the voracity hypothesis, such political inertia may also contribute to suboptimal responses to shocks, by multiplying the number of groups that may exercise effective influence over the fiscal process.

We also include additional control variables. Output per capita (GDP-PC) is included as a general control variable, to check if the level of development has a systemic influence on fiscal cyclicality. This variable is taken from the Penn World Tables and is in PPP terms. In considering the Talvi-Vegh hypothesis, it is potentially important to control for output per

\footnotetext{
${ }^{8}$ That is, how many branches there are to the central government (executive, lower and upper chambers of the legislature) and whether political control of these different branches is unified or held by different parties or coalitions.
} 
capita, since Kraay and Ventura (1999) document an inverse relationship between volatility and the level of output per capita. It follows that the exclusion of output per capita may lead to omitted variable bias in estimating the impact of volatility on cyclicality.

Trade openness (OPEN) is also included. This is also taken from the Penn World Tables and is measured as $(O P E N=0.5 *(\exp +i m p) / G D P)$. If open economies are especially vulnerable to risk, as argued by Rodrik (1998), it may be especially important for the government to faciltate consumption smoothing by operating a countercyclical policy. Finally, we include the size of the public sector (PUBSIZE) as a control variable. This variable is measured as the average ratio of public sector employment to total employment, taken from the OECD database, to capture the potential power of public sector workers in influencing government policy. The public sector workforce is typically highly unionized: we prefer to include PUBSIZE rather than a measure of union power, since unionization indices are available only for a 14-country subset of our sample. ${ }^{9}$ Another reason to include PUBSIZE is that government size and output volatility are negatively correlated in the data (Gali 1994, Fatas and Mihov 2001), such that it is important to control for PUBSIZE in estimating the relation between volatility and fiscal cyclicality.

The sample consists of the 22 "traditional" members of the OECD and we employ annual data over the interval 1960-98. ${ }^{10}$ Debt interest payments are not available for Switzerland, reducing the sample size for some of the regressions.

\subsection{Specification}

In order to obtain measures of the cyclicality in the various categories of government spending, we estimate country-by-country regressions of the form

$$
d\left(\log \left(G_{i t}\right)\right)=\alpha_{i}+\beta_{G i} * d\left(\log \left(Y_{i t}\right)\right)+\varepsilon_{i t}
$$

The coefficient $\beta_{G i}$ is our index of cyclicality in category $i$ of public spending: it measures the elasticity of government expenditure with respect to output growth. ${ }^{11} \mathrm{~A}$ positive value

\footnotetext{
${ }^{9}$ See for example Wallerstein and Western (2000).

${ }^{10}$ For a few countries, some categories of government spending are available for only a more limited interval (e.g. Denmark).

${ }^{11}$ Sorensen et al (2001) explore the relation between the first differences in levels, rather than in logs. This alternative specification implies that the elasticity of public spending to output fluctuations is inversely related to the share of public
} 
of $\beta_{G i}$ implies procyclical behavior; a value above unity implies a more-than-proportionate response to output fluctuations.

Agenor et al (1999), Stein et al (1999) and Talvi and Vegh (1998) measure cyclicality by the correlation between (HP-filtered) government spending and output. However, as pointed out by Forbes and Rigobon (1998), the unadjusted correlation coefficient is potentially misleading when samples have different levels of volatility. ${ }^{12}$ For this reason, since output volatility differs markedly across countries, we prefer the regression-based measure of cyclicality. ${ }^{13}$ This modelling choice is also made by Arreaza et al (1999) and Sorensen et al (2001). However, for completeness, Tables W-1 and W-2 also present the cyclical correlations of the HP-filtered fiscal variables in the web appendix that is available at http://www.elsevier.nl/homepage/sae/econbase/pubec/menu.sht.

We estimate equation (1) by ordinary least squares, with a correction for first-order serial correlation in the error term. This establishes the reduced-form cyclical relation between output and government spending. In analysing fiscal cyclicality, the reduced-form relation may be the most appropriate concept, since there is no strong reason to exclude any equilibrium feedback from fiscal policy to the level of output. However, we also pursue instrumental-variables estimation as a robustness exercise: the details are discussed in the web appendix. ${ }^{14}$

Once the estimates of the cyclicality coefficients are obtained, we seek to explain the cross-country variation with the cross-sectional specification

$$
\hat{\beta}_{i}=\alpha+\lambda * Z_{i}+\nu_{i}
$$

where $\hat{\beta}_{i}$ are the set of estimated parameters from equation (1) and the set of control variables $Z_{i}$ includes output volatility (VOL), the index of power dispersion (POLCON),

spending to GDP. A constant elasticity assumption is a natural benchmark but it would be interesting to explore this alternative hypothesis in future work.

${ }^{12}$ Consider the common data generating process $y=\alpha+\beta x+\varepsilon$. In samples 1 and 2 , the correlations $\rho\left(y_{1}, x_{1}\right)$ and $\rho\left(y_{2}, x_{2}\right)$ will depend on the sample volatilities $\sigma\left(x_{1}\right)$ and $\sigma\left(x_{2}\right)$.

${ }^{13}$ In fact, HP-filtered data deliver very similar results. It also makes little difference if we use the actual output growth rate or the difference between actual output growth and potential output growth rate. See the web appendix for details.

${ }^{14}$ The weighted-average output growth rate of a country's trading partners and the lag of domestic output growthis are employed as instruments for the domestic output growth rate. Tables W-3 and W-4 in the web appendix show that the first-stage regressions have good explanatory power. 
output per capita (GDP-PC), trade openness (OPEN) and the size of the public sector (PUBSIZE). Equation (2) is estimated by weighted least squares. This choice takes account of the fact that the dependent variables are measured with different degrees of precision across countries, depending on the precision of the coefficient estimates in equation (1).

\section{Estimation Results}

\subsection{Measuring Cyclicality}

Tables 1 and 2 report the $\beta$-cyclicality coefficients for the various components of government spending, based on the specification in equation [1]. The mean coefficient values show that current government spending (GCURR) tends to be mildly countercyclical, especially when debt servicing payments are excluded (NIGCURR). However, the government consumption component of current spending (GC) is actually procyclical. In other words, the countercyclical behavior of current government spending emanates from the behavior of government transfers ("automatic stabilizers") and/or debt interest payments. The most procyclical component of government spending is government investment (GI): indeed, it is the only category in which a strict version of the voracity hypothesis applies for some countries, with spending elasticities above unity. The sum of current and investment spending — total government expenditure (GTOT) — is close to being acyclical, especially when debt interest payments are excluded (NIGTOT). Finally, the last column of Table 1 shows that the primary surplus is typically procyclical, in line with tax-smoothing predictions.

However, the average values hide a substantial amount of cross-country variation in fiscal cyclicality across the various categories: the sample standard deviation of cyclicality coefficients are large and the maximum and minimum values establish a large range of estimated parameter values. As such, the stylized facts for such well-studied countries as the United Kingdom and the United States are not representative of the full sample, with these countries displaying more countercyclical fiscal behavior than the average in the sample. In contrast, countries such as Ireland and Portugal exhibit above-average procyclicality in fiscal policy across the range of spending categories. 
Regarding the decomposition of government consumption, Table 2 shows that wage government consumption (WGC) is more procyclical than non-wage government consumption (NWGC). Table 2 shows that public sector wages are typically procyclical but this is not the case for public sector employment. These cyclical patterns are apparently similar to those in the private sector: the ratios (RELW, PUBSIZE) are acyclical on average. Similar to Table 1 , there is considerable cross-country variation in the degree of fiscal cyclicality - wage government consumption is second only to government investment in terms of the dispersion of the estimated cyclicality parameter across countries.

Finally, we have experimented with alternative methods of estimating the cyclicality coefficients. As noted, we also pursue instrumental-variables estimation. We have also tried the following alternatives: using HP-filtered data; measuring output growth relative to potential output growth; adjusting GDP growth for terms of trade fluctuations; and including an election-year dummy in estimating the cyclicality coefficients. As is shown in Table W-5 of the web appendix, there are high correlations in the estimated cyclicality parameters across these alternative specifications.

\subsection{Explaining Variation in Cyclicality across Countries}

Tables 3-4 show the results of cross-sectional regressions that attempt to explain crosscountry variation in the $\beta$-cyclicality indicators for the different components of government spending.

We first consider broad fiscal categories in Table 3. Across columns (1)-(7), we see that the the joint significance of the two main political-economy variables is typically high, as captured by the $\chi_{P O L}^{2}$ statistic. However, this is not the case for total government consumption and government investment in columns (2)-(3) and the POLCON variable is not individually significant or has the wrong sign in regressions (4)-(5) — with respect to the expenditure variables, the POLCON variable is significantly positive only in explaining (overall or non-interest) current government spending in columns (1) and (6). ${ }^{15}$ The indi-

\footnotetext{
${ }^{15}$ That POLCON even has the wrong sign in the GI results in column (3) is somewhat at odds with the case study evidence presented by Tornell and Lane (1998), who emphasize that government investment is a key channel for diversion of resources in developing countries. Greater transparency in the OECD countries may reduce the degree of outright corruption.
} 
vidual performance of the output volatility variable VOL is better: it is also individually significant in explaining (overall or non-interest) total government spending in columns (4)-(5). Finally, column (7) shows the results for the cyclicality of the primary surplus: the significantly positive coefficient on POLCON indicates that power dispersion leads to more procyclical surpluses, despite the procyclicality in current government spending.

Table 4 presents the results for a decomposition of the government consumption spending category. From columns (1)-(2), we see that VOL and POLCON are much more important in explaining procyclicality in wage government consumption (WGC) than in non-wage government consumption (NWGC). Columns (3)-(4) analyze cyclicality in government employment (EG) and public sector real wages (PWAGE): an increase in VOL raises procyclicality in both employment and real wages, whereas the POLCON variables also leads to procyclicality in public sector wages but actually stabilizes government employment. Finally, relative employment in the public sector versus the private sector (EG/ET) and relative real wages (RELW) are analyzed in columns (5)-(6). We observe that VOL has no impact on these variables: more volatile economies also have more procyclicality in private sector wages and employment. However, an increase in power dispersion means more procyclicality in relative government employment and wages, not just in absolute terms.

Regarding the performance of the other control variables, output per capita (GDP-PC) typically exerts a significantly negative influence: richer countries enjoy less procyclical government spending. This is a plausible result, if we think of capability to implement fiscal control procedures being positively correlated with the level of development. In this regard, an especially interesting result is the pattern that relative public wages are more countercyclical in the richer nations in the sample.

Trade openness (OPEN) in contrast typically leads to greater procyclicality in spending (and, conversely, less procyclicality in the primary surplus). It is worth noting that OPEN is especially strong in explaining procyclicality in government investment, with a coefficient that is more than ten times larger than its contribution to the other spending categories.

Finally, we note that the relative size of the government sector (PUBSIZE) generates procyclicality in non-interest government current spending (NIGCURR): from Table 4, we 
see that this emanates from its contribution to procyclicality to wage government consumption, government employment and relative public sector wages. In contrast, we observe that PUBSIZE exerts a countercyclical influence on the primary deficit and government investment. One interpretation of this result is that it is in the long-term interests of public sector workers to maintain fiscal stability (via a procyclical fiscal surplus) and procyclicality in public sector wages crowds out government investment to this end.

Taken together, the results in Tables 3-4 provide considerable support for political economy factors in determining variation in fiscal cylicality across OECD countries. ${ }^{16}$ Moreover, these factors vary in importance across spending categories, with wage government consumption emerging as an important channel by which these variables exert an influence. Tables 3-4 also provide some interesting evidence concerning the roles played by other national characteristics (output per capita, trade openness and the relative size of the government sector) in determining cross-country variation in fiscal cyclicality.

\section{Conclusions}

Our empirical results broadly support the contention that political economy factors play an important role in determining the degree of cyclicality in government spending across OECD countries. In future work, this study could be extended in a number of directions. Most obviously, it would be desirable to enlarge the sample size by including non-OECD countries. However, this would involve developing a framework that could take into account the possible role played by international financial crises in inducing forced fiscal procyclicality in some emerging market economies.

Detailed country studies of episodes of fiscal procyclicality would be a useful complement to the cross-sectional empirical analysis conducted in this paper. In particular, documenting the roles played by various individual political groups in generating aggregate

\footnotetext{
${ }^{16}$ We cross-check these results by employing the instrumental-variables estimates of the cyclicality parameters as the dependent variables in Tables W-6 and W-7 of the web appendix, with an actual improvement in the results for the political economy variables VOL and POLCON relative to Tables 3 and 4. First, the coefficients on VOL and POLCON are typically larger in absolute magnitude. Second, VOL now generates a less procyclical fiscal surplus in column (7) of Table W-6, in line with the Talvi-Vegh hypothesis. Third, the results for POLCON are now more in line with theoretical priors along several dimensions: for instance, its impact on GTOT and NIGTOT is now significantly positive.
} 
fiscal procyclicality would be enlightening in studying the operation of the voracity effect. From a policy perspective, it would be useful to understand the roles played by formal fiscal rules and fiscal institutions in determining the degree of fiscal cyclicality. Finally, it is interesting to speculate that the role played by power dispersion may involve a basic trade-off: a more predictable policy environment (on account of induced policy inertia) is obtained in exchange for suboptimally procyclical behavior over the business cycle.

\section{References}

Agenor, P., McDermott, J., Prasad, E., 1999. Macroeconomic fluctuations in developing countries: Some stylized facts. International Monetary Fund WP/99/35.

Alesina, A., Perotti, R., 1995. Fiscal expansions and adjustments in OECD economies. Economic Policy, 21, 207-248.

Arreaza, A., Sorensen, B.E., Yosha, O., 1999. Consumption smoothing through fiscal policy in OECD and EU countries. In: Poterba, J.M, von Hagen, J. (Eds) Fiscal Institutions and Fiscal Performance. University of Chicago Press, Chicago IL, 59-80.

Barro, R.J., 1979. On the determination of the public debt. Journal of Political Economy 87, 940-971.

Barro, R.J., Sala-i-Martin, X., 1995. Economic Growth. McGraw-Hill, New York.

Bayoumi, T., Eichengreen, B., 1995. Restraining yourself: Fiscal rules and stabilization. International Monetary Fund Staff Papers 42, 32-48.

Blanchard, O., Fischer, S.,1989. Lectures on Macroeconomics. The MIT Press, Cambridge, MA.

Fatas, A.,Mihov, I., 2001. Government size and automatic stabilizers: International and intranational evidence. Journal of International Economics 55, 3-28.

Forbes, K., Rigobon, R., 1998. No contagion, only interdependence: Measuring stock market co-movements. NBER Working Paper \#7267. 
Gali, J., 1994. Government size and macroeconomic stability. European Economic Review $38,117-132$.

Gavin, M., Hausmann, R., Perotti, R., Talvi, E., 1996. Managing fiscal policy in Latin America and the Caribbean: Volatility, procyclicality and limited creditworthiness. Mimeo, Inter-American Development Bank.

Gavin, M., Perotti, R., 1997. Fiscal policy in Latin America. NBER Macroeconomics Annual 1997, 12, 11-70.

Henisz, W., 1999. The institutional environment for economic growth. Mimeo, Wharton School of Management.

Hercowitz, Z., Strawczynski, M., 1999. Cyclical bias in government spending: Evidence from the OECD. Mimeo, Tel Aviv University.

Kraay, A., Ventura, J., 1999. Comparative advantage and the cross-section of business cycles. Mimeo, MIT.

Lane, P.R., 1998. On the cyclicality of Irish fiscal policy. Economic and Social Review $29,1-17$.

Lane, P. R., Tornell, A., 1996. Power, growth and the voracity effect. Journal of Economic Growth 1, 213-241.

Lane, P. R., Tornell, A., 1998. Why aren't Latin American savings rates procyclical? Journal of Development Economics 57, 185-200.

Lucas, R.E., Stokey, N.L., 1983. Optimal fiscal and monetary policy in an economy without capital. Journal of Monetary Economics 12, 55-94.

Missale, A., 1999. Public Debt Management, Oxford, UK: Oxford University Press.

Sorensen, B. E., Wu, L., Yosha, O., 2001. Output fluctuations and fiscal policy: US state and local governments 1978-1994. European Economic Review 45, 1271-1310. 
Stein, E., Talvi, E., Gristani, A., 1999. Institutional arrangements and fiscal performance: The Latin American experience. In: Poterba, J.M., von Hagen, J. (Eds) Fiscal Institutions and Fiscal Performance. University of Chicago Press, Chicago IL, 103134 .

Svensson, J., 1996. Collusion among interest groups: Foreign aid and rent dissipation. Mimeo, The World Bank.

Talvi, E., Vegh, C., 2000. Tax base variability and procyclical fiscal policy. NBER Working Paper \# 7499.

Taylor, J. B., Woodford, M. (Eds), 1999. Handbook of Macroeconomics, North-Holland, Amsterdam.

Tornell, A., Lane, P.R., 1998. Are windfalls a curse? A non-representative agent model of the current account. Journal of International Economics 44, 83-112.

Tornell, A., Lane, P.R., 1999. The voracity effect. American Economic Review 89, 22-46.

Wallerstein, M., Western, B., 2000. Unions in decline? What has changed and why. Annual Review of Political Science 3, 355-377. 
Table 1: Cyclicality Coefficients: Broad Categories

\begin{tabular}{cccccccc}
\hline & GCURR & GC & GI & GTOT & NIGTOT & NIGCURR & PSY \\
\hline AUS & -0.01 & 0.10 & -0.08 & -0.09 & -0.35 & -0.32 & 0.30 \\
AUT & -0.18 & 0.14 & 1.39 & -0.13 & -0.20 & -0.27 & 0.18 \\
BEL & -0.24 & -0.18 & 1.75 & -0.22 & -0.26 & -0.28 & 0.14 \\
CAN & -0.51 & -0.34 & 0.60 & -0.41 & -0.49 & -0.60 & 0.59 \\
DEN & 0.31 & 0.37 & 0.67 & 0.33 & 0.37 & 0.35 & 0.04 \\
FIN & -0.30 & -0.03 & 0.67 & -0.37 & -0.38 & -0.30 & 0.44 \\
FRA & -0.49 & -0.16 & 0.55 & -0.41 & -0.31 & -0.38 & 0.33 \\
GER & -0.29 & -0.08 & 1.82 & -0.13 & -0.07 & -0.22 & 0.40 \\
GRC & -0.03 & 0.45 & 1.58 & 0.35 & 0.52 & 0.17 & -0.07 \\
ICE & 0.21 & 0.91 & 1.18 & 0.28 & 0.45 & 0.46 & 0.17 \\
IRE & 0.26 & 0.57 & 1.67 & 0.43 & 0.43 & 0.26 & -0.03 \\
ITA & -0.66 & -0.14 & 0.29 & -0.65 & -0.58 & -0.59 & 0.09 \\
JAP & -0.02 & 0.08 & 1.11 & 0.41 & 0.40 & -0.05 & 0.10 \\
NET & -0.22 & 0.40 & 1.28 & -0.19 & -0.13 & -0.17 & 0.23 \\
NOR & 0.57 & 0.60 & 1.50 & 0.68 & 0.17 & 0.12 & 0.73 \\
NZL & 0.03 & -0.12 & 0.30 & 0.30 & 0.45 & 0.16 & 0.31 \\
PRT & 0.39 & 0.61 & 0.44 & 0.37 & 0.48 & 0.51 & 0.16 \\
ESP & -0.01 & 0.68 & 0.80 & -0.02 & 0.04 & 0.02 & 0.14 \\
SWE & -0.32 & 0.13 & 1.09 & -0.21 & -0.37 & -0.36 & 0.85 \\
SWI & 0.20 & 0.35 & 1.35 & 0.34 & & & \\
UK & -0.43 & -0.54 & -1.67 & -0.43 & -0.69 & -0.83 & 0.37 \\
US & -0.14 & 0.03 & 0.17 & -0.10 & -0.14 & -0.20 & 0.37 \\
Mean & -0.09 & 0.17 & 0.84 & 0.01 & -0.03 & -0.12 & 0.28 \\
St.Dev. & 0.32 & 0.37 & 0.79 & 0.36 & 0.39 & 0.36 & 0.23 \\
Max & 0.57 & 0.91 & 1.82 & 0.68 & 0.52 & 0.51 & 0.85 \\
Min & -0.66 & -0.54 & -1.67 & -0.65 & -0.69 & -0.83 & -0.07 \\
Median & -0.09 & 0.11 & 0.95 & -0.10 & -0.13 & -0.20 & 0.23 \\
\hline & & & & & & & \\
\hline
\end{tabular}

Cyclicality $(\beta)$ coefficients generated by equation (1) over 1960-1998. For some countries, data interval is shorter. Source of fiscal and output data is OECD Economic Outlook database. GCURR is government current spending. GC is government consumption, GI is government investment, GTOT is sum of GCURR and GI. NIGTOT is GTOT minus debt interest; NIGCURR is GCURR minus debt interest; PSY is ratio of primary surplus to GDP. OLS estimation, with AR(1) correction. 
Table 2: Cyclicality Coefficients: Government Consumption and Employment

\begin{tabular}{|c|c|c|c|c|c|c|}
\hline & WGC & NWGC & EG & PWAGE & $\mathrm{EG} / \mathrm{ET}$ & RELW \\
\hline AUS & -0.26 & 0.77 & -0.46 & 0.58 & 0.24 & -0.06 \\
\hline $\mathrm{AUT}$ & -0.15 & 0.66 & 0.11 & -0.18 & -0.09 & 0.01 \\
\hline BEL & 0.08 & -0.78 & 0.01 & 0.11 & -0.32 & -0.01 \\
\hline CAN & -0.27 & -0.22 & -0.05 & -0.10 & -0.22 & -0.04 \\
\hline $\mathrm{DEN}$ & -0.13 & -0.83 & 0.02 & -0.06 & 0.11 & -0.01 \\
\hline FIN & 0.01 & 0.17 & 0.05 & -0.15 & -0.23 & -0.01 \\
\hline FRA & -0.13 & -0.07 & -0.01 & -0.07 & 0.05 & -0.02 \\
\hline GER & 0.07 & -0.04 & -0.07 & 0.23 & -0.10 & -0.45 \\
\hline GRC & 0.36 & 0.10 & 0.12 & 0.47 & -1.08 & 0.01 \\
\hline ICE & 1.33 & -0.21 & 0.00 & 1.23 & -0.15 & -0.03 \\
\hline IRE & 0.28 & 1.13 & 0.08 & 0.15 & -0.31 & -0.03 \\
\hline ITA & 0.16 & -0.51 & 0.04 & 0.03 & -0.12 & 0.01 \\
\hline JAP & 0.05 & 0.26 & 0.04 & 0.21 & -0.06 & -0.01 \\
\hline NET & -0.18 & -0.13 & -0.04 & -0.08 & -0.33 & -0.02 \\
\hline NOR & 0.92 & 0.40 & 0.15 & 0.78 & 0.30 & 0.01 \\
\hline NZL & 0.70 & -1.09 & -0.03 & 0.66 & 0.08 & -0.02 \\
\hline PRT & 0.62 & 0.56 & -0.04 & 0.70 & 1.13 & 0.00 \\
\hline ESP & 0.81 & -0.04 & 0.17 & 0.50 & 0.55 & -0.03 \\
\hline SWE & 0.07 & 0.68 & 0.26 & -0.23 & -0.21 & -0.03 \\
\hline SWI & 0.48 & 0.24 & 0.09 & 0.30 & -0.13 & 0.00 \\
\hline UK & -1.63 & 0.52 & 0.05 & -0.70 & 0.54 & 0.00 \\
\hline US & 0.12 & -0.08 & 0.02 & 0.11 & -0.06 & -0.03 \\
\hline Mean & 0.15 & 0.07 & 0.02 & 0.20 & -0.02 & -0.03 \\
\hline St.Dev. & 0.58 & 0.55 & 0.13 & 0.43 & 0.42 & 0.09 \\
\hline Max & 1.33 & 1.13 & 0.26 & 1.23 & 1.13 & 0.01 \\
\hline Min & -1.63 & -1.09 & -0.46 & -0.70 & -1.08 & -0.45 \\
\hline Median & 0.08 & 0.03 & 0.03 & 0.13 & -0.10 & -0.01 \\
\hline
\end{tabular}

Cyclicality $(\beta)$ coefficients generated by equation (1) over 1960-1998. For some countries, data interval is shorter. Source of fiscal and output data is OECD Economic Outlook database. WGC is wage government consumption, NWGC is nonwage government consumption, EG is government employment, PWAGE is public sector wage rate, EG/ET is ratio of public sector to total employment, RELW is ratio of public sector wage tolpivate sector wage. OLS estimation, with AR(1) correction. 
Table 3: Determinants of Fiscal Cyclicality: Broad Categories

\begin{tabular}{cccccccc}
\hline & $\begin{array}{c}(1) \\
\text { GCURR }\end{array}$ & $\begin{array}{c}(2) \\
\text { GC }\end{array}$ & $\begin{array}{c}(3) \\
\text { GI }\end{array}$ & GTOT & NIGTOT & NIGCURR & PSY \\
\hline C & 2.92 & 4.41 & -3.37 & 0.98 & 2.12 & 4.5 & -0.76 \\
& $(3.05)^{* * *}$ & $(3.68)^{* * *}$ & $(1.26)$ & $(1.02)$ & $(2.24)^{* *}$ & $(10.98)^{* * *}$ & $(1.24)$ \\
VOL & 0.17 & 0.1 & 0.21 & 0.26 & 0.39 & 0.27 & 0.02 \\
& $(4.76)^{* * *}$ & $(1.11)$ & $(1.58)$ & $(18.7)^{* * *}$ & $(12.41)^{* * *}$ & $(6.5)^{* * *}$ & $(.81)$ \\
POLCON & 0.83 & 0.21 & -1.99 & -0.44 & -0.33 & 0.58 & 0.6 \\
& $(4.36)^{* * *}$ & $(.91)$ & $(1.34)$ & $(1.77)^{*}$ & $(1.35)$ & $(3.03)^{* * *}$ & $(4.44)^{* * *}$ \\
GDP-PC & -0.48 & -0.53 & 0.53 & -0.17 & -0.34 & -0.67 & 0.004 \\
& $(3.73)^{* * *}$ & $(4.51)^{* * *}$ & $(1.47)$ & $(1.34)$ & $(2.76)^{* *}$ & $(10.39)^{* * *}$ & $(.05)$ \\
OPEN & 0.007 & 0.008 & 0.033 & 0.01 & 0.006 & 0.007 & -0.004 \\
PUBSIZE & $(2.76)^{* *}$ & $(2.3)^{* *}$ & $(7.96)^{* * *}$ & $(3.44)^{* * *}$ & $(4.72)^{* * *}$ & $(4.83)^{* * *}$ & $(2.48)^{* *}$ \\
& 0.79 & 0.12 & -3.93 & 0.17 & 0.53 & 1.28 & 3.77 \\
$\chi_{P O L}^{2}$ & $(.89)$ & $(.12)$ & $(2.5)^{* *}$ & $(.2)$ & $(.93)$ & $(2.31)^{* *}$ & $(6.09)^{* * *}$ \\
$R^{2}$ & $27.9 * * *$ & 1.4 & $6.3^{* * *}$ & $573.7^{* * *}$ & $176.3^{* * *}$ & $42.6^{* * *}$ & $20.1 * * *$ \\
\hline & 0.23 & 0.22 & 0.3 & 0.29 & 0.55 & 0.48 & 0.52 \\
\hline
\end{tabular}

Source of fiscal and output data is OECD Economic Outlook database. GCURR is government current spending. GC is government consumption, GI is government investment, GTOT is sum of GCURR and GI. NIGTOT is GTOT minus debt interest; NIGCURR is GCURR minus debt interest; PSY is ratio of primary surplus to GDP. Output volatility VOL is measured as the standard deviation of the GDP growth rate. The measure of power dispersion POLCON is taken from Henisz (2000). This $(0,1)$ index counts the number of veto points in the political system and the distribution of preferences across and within the different branches of the government. $\chi_{P O L}^{2}$ is test of joint significance of VOL and POLCON. Output per capita (GDP-PC) is taken from the Penn World Tables and is in PPP terms. Trade openness (OPEN) is also taken from the Penn World Tables and is measured as $(0.5 *(\exp +i m p) / G D P)$. PUBSIZE is measured as the average ratio of public sector employment to total employment. t-statistics in parentheses. ${ }^{* * *},{ }^{* *},{ }^{*}$ denote significance at the 1,5 and 10 percent levels respectively. Weighted least squares estimation. 
Table 4: Determinants of Fiscal Cyclicality: Government Consumption and Employment

\begin{tabular}{ccccccc}
\hline & $(1)$ & $(2)$ & $(3)$ & $(4)$ & $(5)$ & $(6)$ \\
& WGC & NWGC & EG & PWAGE & EG/ET & RELW \\
\hline C & 1.35 & 8.39 & 0.57 & 0.61 & 2.31 & 6.19 \\
& $(1.71)$ & $(5.21)^{* * *}$ & $(1.03)$ & $(1.03)$ & $(2.2)^{* *}$ & $(3.65)^{* * *}$ \\
VOL & 0.53 & -0.86 & 0.24 & 0.41 & 0.004 & 0.008 \\
& $(21.5)^{* * *}$ & $(1.69)$ & $(2.28)^{* *}$ & $(7.93)^{* * *}$ & $(.25)$ & $(.22)$ \\
POLCON & 0.87 & 0.63 & -0.63 & 1.13 & -1.28 & 3.51 \\
& $(2.33)^{* *}$ & $(1.02)$ & $(2.64)^{* *}$ & $(3.67)^{* * *}$ & $(3.64)^{* * *}$ & $(8.51)^{* * *}$ \\
GDP-PC & -0.41 & -0.86 & -0.03 & -0.26 & -0.19 & -1.0 \\
& $(3.74)^{*}$ & $(5.36)^{* * *}$ & $(.41)$ & $(3.53)^{* * *}$ & $(1.44)$ & $(4.5)^{* * *}$ \\
OPEN & 0.004 & -0.002 & 0.002 & -0.001 & 0.005 & -0.006 \\
& $(2.32)^{* *}$ & $(.29)$ & $(2.26)^{* *}$ & $(.96)$ & $(4.76)^{* * *}$ & $(1.97)^{* *}$ \\
PUBSIZE & 2.65 & -0.3 & 0.8 & 0.68 & 0.07 & 2.21 \\
& $(4.01)^{* * *}$ & $(.13)$ & $(1.77)^{*}$ & $(1.04)$ & $(.21)$ & $(1.86)^{* *}$ \\
$\chi_{\text {POL }}^{2}$ & $579.1^{* * *}$ & $5.3 *$ & $18.8^{* * *}$ & $63.1^{* * *}$ & $13.7^{* * *}$ & $74.3^{* * *}$ \\
$R^{2}$ & 0.29 & 0.2 & 0.22 & 0.3 & 0.47 & 0.34 \\
\hline
\end{tabular}

Source of fiscal and output data is OECD Economic Outlook database. WGC is wage government consumption, NWGC is nonwage government consumption, EG is government employment, PWAGE is public sector wage rate, EG/ET is ratio of public sector to total employment, RELW is ratio of public sector wage to private sector wage.Output volatility VOL is measured as the standard deviation of the GDP growth rate. The measure of power dispersion POLCON is taken from Henisz (2000). This $(0,1)$ index counts the number of veto points in the political system and the distribution of preferences across and within the different branches of the government.Output per capita (GDP-PC) is taken from the Penn World Tables and is in PPP terms. Trade openness (OPEN) is also taken from the Penn World Tables and is measured as $(0.5 *(\exp +i m p) / G D P)$. PUBSIZE is measured as the average ratio of public sector employment to total employment. $\chi_{P O L}^{2}$ is test of joint significance of VOL and POLCON. t-statistics in parentheses. ${ }^{* * *}, * *, *$ denote significance at the 1,5 and 10 percent levels respectively. Weighted least squares estimation. 